\title{
COVID-19 and Asthma: Reflection During the Pandemic
}

\author{
Shuang Liu ${ }^{1,2} \cdot$ Yuxiang $\mathrm{Zhi}^{1}$ (D) $\cdot$ Sun Ying $^{3}$ \\ Published online: 28 May 2020 \\ (C) Springer Science+Business Media, LLC, part of Springer Nature 2020
}

\begin{abstract}
Coronavirus disease 2019 (COVID-19) is a global pandemic infectious disease caused by severe acute respiratory syndrome coronavirus-2 (SARS-CoV-2), and abnormal, overactivated innate immunity and "cytokine storms" have been proposed as potential pathological mechanisms for rapid COVID-19 progression. Theoretically, asthmatic patients should have increased susceptibility and severity for SARS-CoV-2 infection due to a deficient antiviral immune response and the tendency for exacerbation elicited by common respiratory viruses. However, existing studies have not shown an expected prevalence of asthmatic individuals among COVID-19 patients. Certain aspects of type 2 immune response, including type 2 cytokines (IL4, IL-13, etc.) and accumulation of eosinophils, might provide potential protective effects against COVID-19. Furthermore, conventional therapeutics for asthma, including inhaled corticosteroids, allergen immunotherapy (AIT), and anti-IgE monoclonal antibody, might also reduce the risks of asthmatics suffering infection of the virus through alleviating inflammation or enhancing antiviral defense. The interactions between COVID-19 and asthma deserve further attention and clarification.
\end{abstract}

Keywords COVID-19 $\cdot$ SARS-CoV-2 $\cdot$ Asthma $\cdot$ Allergic diseases $\cdot$ Type 2 immune response

\section{Introduction}

Coronaviruses (CoVs) are the largest known positive-sense RNA viruses, with a wide range of hosts, and have seriously affected human and animal health. CoVs known to infect humans include low-pathogenicity CoVs (CoV-229E, CoVNL63, CoV-OC43, and CoV-HKU1) usually causing mild to moderate illness and high-pathogenicity CoVs that can lead to severe, potentially lethal diseases. In the twenty-first century, outbreaks of infections with severe acute respiratory syndrome coronavirus (SARS-CoV) and Middle East respiratory

Yuxiang Zhi

yuxiang_zhi@126.com

Sun Ying

ying.sun@ccmu.edu.cn

1 Department of Allergy \& Clinical Immunology, National Clinical Research Center for Immunologic Diseases, Peking Union Medical College Hospital, Peking Union Medical College \& Chinese Academy of Medical Sciences, \#1 Shuaifuyuan, Wangfujing, Dongcheng District, Beijing 100730, China

2 School of Clinical Medicine, Chinese Academy of Medical Sciences \& Peking Union Medical College, Beijing 100005, China

3 Department of Immunology, School of Basic Medical Science, Capital Medical University, \#10, Xitoutiao, Youanmenwai, Fengtai District, Beijing 100069, China syndrome coronavirus (MERS-CoV) have caused massive impacts on public health as well as socioeconomic aspects. Notably, the pandemic of coronavirus disease 2019 (COVID-19) caused by the novel CoV severe acute respiratory syndrome coronavirus 2 (SARS-CoV-2) has posed a serious threat to global health since December 2019. According to the World Health Organization, there are 3,090,445 reported cases and 217,769 deaths up to 30 April 2020, 08:00 GMT+8. The numbers are still rising rapidly.

Virologically, SARS-CoV-2, sharing $79.6 \%$ sequence identity with SARS-CoV and $96 \%$ with a bat $\mathrm{CoV}$ [1], belongs to the beta-coronavirus family, which also includes SARS-CoV and MERS-CoV. It has been believed that SARS-CoV-2 spreads predominantly by droplets, aerosols, and contact transmission and can also be detected in stool, urine, and blood [2,3], although how the virus gets there remains a mystery. The majority of infected people have mild or no symptoms, but a proportion of patients display severe and rapid progression of the disease, leading to acute lung injury/acute respiratory distress syndrome and/or multiple organ failure $[4,5]$. The median incubation period is estimated to be 5.1 days, with $97.5 \%$ of symptomatic infections becoming evident within 11.5 days [6]. The most common symptoms include fever $(88.5 \%)$, cough $(68.6 \%)$, myalgia or fatigue (35.8\%), expectoration (28.2\%), and dyspnea (21.9\%) [7]. Laboratory examinations have shown that severe COVID19 patients have decreased numbers of neutrophils, 
lymphocytes, and eosinophils and neutrophil-to-lymphocyte ratios, suggesting that abnormal, overactivated immune immunity might be a possible mechanism.

Although their exceptionally large genomes enable CoVs to optimize the environment for replication by interacting with host cells [8], host factors are essential in the pathogenesis of $\mathrm{CoV}$ infection. It is recognized that compared with others, people with underlying diseases, including hypertension, diabetes mellitus, and cardiovascular and cerebrovascular diseases, more easily develop severe illness and have a worse prognosis [9]. In contrast, asthma, with a high prevalence (estimated $4.2 \%$ in the Chinese population [10] and 8.4\% in the USA [11]) and potentially pathological changes in the respiratory system, has not been adequately documented in people suffering from COVID19. Considering the relatively high prevalence of asthma, it is reasonable to hypothesize that asthmatic individuals are relatively resistant to COVID-19 because of the features of the disease and/or the conventional treatment for asthma. The following discusses how asthma patients protect themselves from the virus infection pandemic and how asthma affects COVID19 susceptibility and the disease course. All of these aspects should be carefully examined.

However, the current understanding of the interactions between CoVs and asthma is still in the early stages, while observational and experimental data are still awaited to elucidate the relationship between COVID-19 and asthma. The purpose of this review is to summarize the current understanding of the possible interactions between these disease entities and to discuss the potential protective effects of asthma therapeutics in the context of COVID-19.

\section{The Pathophysiology of COVID-19}

SARS-CoV-2 enters the host cell through targeting angiotensin-converting enzyme II (ACE2), the same receptor as SARS-CoV [1], which might further trigger host immune responses based on previous knowledge of CoVs. After entering the cytoplasm, SARS-CoV releases genomic RNA and begins replication in the host cell. The presence of doublestranded RNA (dsRNA) can elicit an innate immune response through sensitizing Toll-like receptor (TLR)-3 and then activating type 1 interferon (IFN) production by signalling pathway cascades [12]. Type 1 IFNs are important antiviral cytokines that can induce the expression of interferon-stimulated genes (ISGs) [8]. On the other hand, the spike protein (S protein) of the virus might be recognized by TLR-4 and lead to activation of pro-inflammatory cytokines through the MyD88-dependent signalling pathway, recruiting lymphocytes and leukocytes to the infection site [8]. Regarding adaptive immune responses, $\mathrm{CoV}$ antigens are presented to $\mathrm{T}$ cells by antigen-presenting cells (APCs), which leads to T cell activation and differentiation [12]. This process, which may be accompanied by massive release of pro-inflammatory cytokines, is vital for viral clearance but has the potential to induce overactivated inflammation.

Orchestration between the innate and adaptive immune systems is essential in antiviral responses. If adaptive immune responses are insufficient to eliminate the virus, innate immune responses are likely to be reinforced, which may lead to uncontrollable inflammation [13]. Accumulating evidence derived from COVID-19 patients leads to a putative mechanism of a cytokine storm, which is based on an elevated proinflammatory cytokine profile resembling a cytokine storm, especially in severe patients [14]. In a study, Huang et al. measured multiple cytokines in 41 COVID-19 patients (including 13 ICU patients and 28 non-ICU patients) and found that there were higher levels of interleukin (IL) $1 \beta$, IL-1R $\alpha$, IL-7, IL-8, IL-9, IL-10, basic fibroblast growth factor (FGF), granulocyte-colony stimulating factor (G-CSF), granulocytemacrophage colony stimulating factor (GM-CSF), IFN- $\gamma$, interferon- $\gamma$-inducible protein (IP-10), monocyte chemoattractant protein (MCP-1), macrophage inflammatory protein 1 alpha (MIP-1 $\alpha$ ), macrophage inflammatory protein 1 beta (MIP-1 $\beta$ ), platelet-derived growth factor (PDGF), tumor necrosis factor (TNF- $\alpha$ ), and vascular endothelial growth factor (VEGF) in COVID-19 patients than in healthy controls [4]. The same authors have also noted that there were higher concentrations of IL-2, IL-7, IL-10, G-CSF, IP-10, MCP-1, MIP- $1 \alpha$, and TNF- $\alpha$ in ICU patients than in non-ICU patients [4]. In addition, significant elevation of IL-6 levels, especially in severe patients, has been reported in several studies [15-19]. Cytokines reported to be altered in COVID-19 patients are summarized in Table 1.

It has been proposed that severe COVID-19 patients have a cytokine profile resembling secondary hemophagocytic lymphohistiocytosis (sHLH), accompanying rapid progression of lung injury and multiorgan damage [20]. Moreover, there are notable signs showing immune system damage manifesting as extreme lymphopenia and spleen and lymph node atrophy in severe COVID-19 patients [14]. Currently, some anti-inflammatory drugs, including glucocorticoids, tocilizumab (TCZ, an anti-human IL-6 monoclonal antibody), and Janus kinase (JAK) inhibitors, have been applied in COVID-19 therapy but await additional clinical evidence to evaluate safety and efficacy.

The pathological understanding of COVID-19 is still growing. The first published pathological report generated in 2 patients from Wuhan, China, showed edema, proteinaceous exudate, focal reactive hyperplasia of pneumocytes with patchy inflammatory cellular infiltration and multinucleated giant cells, suggesting early phase pulmonary changes [21]. Investigation of a patient who died of severe COVID-19 revealed evident desquamation of pneumocytes and hyaline membrane formation, which are similar to what was observed in SARS and MERS [22]. Other pathological examinations 
Table 1 Cytokine profiles reported in COVID-19 patients

\begin{tabular}{|c|c|c|}
\hline Cytokines or chemokines & Changes in COVID-19 & References \\
\hline \multirow[t]{2}{*}{ IL-1 $\beta$} & Increase in COVID-19 patients & {$[4]$} \\
\hline & Undetectable in COVID-19 patients & {$[16]$} \\
\hline IL-1R $\alpha$ & Increase in COVID-19 patients & {$[4]$} \\
\hline \multirow[t]{2}{*}{ IL-2 } & Increase in severe COVID-19 patients & {$[4]$} \\
\hline & No significant change & {$[17]$} \\
\hline IL-2R & Increase in severe COVID-19 patients & {$[15]$} \\
\hline \multirow[t]{2}{*}{ IL-4 } & Increase in severe COVID-19 patients & {$[4]$} \\
\hline & No significant change & {$[17,20]$} \\
\hline IL-5 & No significant change compared to healthy controls & {$[4]$} \\
\hline \multirow[t]{2}{*}{ IL-6 } & Increase in severe COVID-19 patients & {$[4,20]$} \\
\hline & Increase in COVID-19 patients, higher in severe patients & {$[15-18]$} \\
\hline IL-7 & Increase in COVID-19 patients, higher in severe patients & {$[4]$} \\
\hline \multirow[t]{2}{*}{ IL-8 (CXCL8) } & Increase in COVID-19 patients & {$[4]$} \\
\hline & Within normal range & {$[15]$} \\
\hline IL-9 & Increase in COVID-19 patients & {$[4]$} \\
\hline \multirow[t]{3}{*}{ IL-10 } & Increase in COVID-19 patients, higher in severe patients & {$[4,17]$} \\
\hline & Increase in severe COVID-19 patients & {$[15]$} \\
\hline & Within normal range & {$[20]$} \\
\hline IL-12 (p70) & No significant change & {$[4]$} \\
\hline IL-13 & Increase in severe COVID-19 patients & {$[4]$} \\
\hline IL-15 & No significant change & {$[4]$} \\
\hline \multirow[t]{2}{*}{ IL-17 } & Increase in severe COVID-19 patients & {$[4]$} \\
\hline & Within normal range & {$[20]$} \\
\hline Eotaxin (CCL11) & No significant change & {$[4]$} \\
\hline Basic FGF & Increase in COVID-19 patients & {$[4]$} \\
\hline G-CSF & Increase in COVID-19 patients, higher in severe patients & {$[4]$} \\
\hline GM-CSF & Increase in COVID-19 patients & {$[4]$} \\
\hline \multirow[t]{2}{*}{$\mathrm{IFN} \gamma$} & Increase in COVID-19 patients & {$[4]$} \\
\hline & No significant change & {$[17]$} \\
\hline IP10 (CXCL10) & Increase in COVID-19 patients, higher in severe patients & {$[4]$} \\
\hline MCP-1 (CCL2) & Increase in COVID-19 patients, higher in severe patients & {$[4]$} \\
\hline MIP-1 $\alpha(C C L 3)$ & Increase in COVID-19 patients, higher in severe patients & {$[4]$} \\
\hline MIP-1 $\beta$ (CCL4) & Increase in COVID-19 patients & {$[4]$} \\
\hline PDGF & Increase in COVID-19 patients & {$[4]$} \\
\hline RANTES (CCL5) & No significant change & {$[4]$} \\
\hline \multirow[t]{2}{*}{ TNF- $\alpha$} & Increase in COVID-19 patients, higher in severe patients & {$[4]$} \\
\hline & Increase in severe COVID-19 patients & {$[4,15,17]$} \\
\hline VEGF- $\alpha$ & Increase in COVID-19 patients & {$[4]$} \\
\hline
\end{tabular}

$I L$, interleukin; $C X C L$, chemokine (C-X-C motif) ligand; $C C L$, C-C motif chemokine; $F G F$, fibroblast growth factor; $G-C S F$, granulocyte-colony stimulating factor; $G M-C S F$, granulocyte-monocyte colony-stimulating factor; $I F N$, interferon; $I P 10$, interferon- $\gamma$ inducible protein $10 ; M C P-1$, monocyte chemo-attractant protein $1 ; M I P 1$ $\alpha$, macrophage inflammatory protein $1-\alpha ; M I P 1-\beta$, macrophage inflammatory protein $1-\beta ; P D G F$, plateletderived growth factor; RANTES, Regulated upon Activation, Normal T Cell Expressed and Presumably Secreted; $T N F-\alpha$, tumor necrosis factor $\alpha ; V E G F$, vascular endothelial growth factor

derived from 2 fatal COVID-19 cases in Wuhan, China, showed that there were mucous plugs with fibrinous exudate in the alveoli and activation of alveolar macrophages because these macrophages had strong expression of IL-10 and programmed death-ligand 1 (PD-L1) and moderate expression of IL-6 and TNF- $\alpha$ [23].

\section{The Pathophysiology of Asthma}

Asthma is a common respiratory disease characterized by airway chronic inflammation, mucus overproduction, hyperresponsiveness, and remodelling. Normally, the majority of the disease is predominantly mediated by type 2 immune 
responses. The type 2 immune response involves $\mathrm{T}$ helper (Th) 2 cells, type 2 B cells, group 2 innate lymphoid cells, type 2 macrophages, IL-4-secreting nature killer (NK) and natural killer T (NKT) cells, basophils, eosinophils, and mast cells [24]. A variety of cytokines produced by immune system and epithelial cells contribute to the regulatory network. For example, IL-4 and IL-13 have essential roles in allergenspecific immunoglobin (Ig) E production and accumulation of Th2 cells and eosinophils in local tissues, as well as epithelial barrier regulation, while IL-5, IL-9, and IL-13 contribute to eosinophilia and mucus production [25].

\section{Pre-existing Asthma and COVID-19}

\section{Deficient Antiviral Response in Asthmatic Patients}

It is generally acknowledged that antiviral and allergic responses are two distinct arms in immunity and are reciprocally regulated, involving a comprehensive interaction network [26]. IFNs, a family of important antiviral cytokines, play a central role in this regulatory network. It has been proposed that individuals with asthma are predisposed to allergic responses that might override the antiviral response, manifesting as elevated susceptibility and a deficient immune response to viral infection [26].

Previous studies have shown that IFN production by bronchial epithelial cells and plasmacytoid dendritic cells (pDCs) is impaired in asthmatic individuals [27-30]. It has also been shown that there is reduced production of IFN- $\beta$ in asthmatic bronchial epithelial cells, accounting for impaired apoptosis and increased rhinovirus (RV) replication [27]. Deficient IFN- $\alpha / \beta$ expression by bronchial epithelial cells has also been noted in asthmatic patients after RV infection, which is associated with increased viral load and adverse clinical outcomes [28]. In addition, deficient induction of IFN- $\lambda$ by RV in bronchial epithelial cells and alveolar macrophages has also been observed in vivo, which is highly correlated with the viral load and severity of asthma exacerbations [29]. Upon exposure to influenza $\mathrm{A}, \mathrm{pDCs}$ from asthmatic patients produce less IFN $-\alpha$ than those from healthy controls [30].

Furthermore, IgE cross-linking, a hallmark of allergic diseases, is able to dampen antiviral immune responses through abrogating the IFN- $\alpha$ response, diminishing TLR-7 upregulation, and interrupting pDC maturation [30], while concentrations of serum IgE are inversely correlated with a reduction in IFN- $\alpha$ secretion [30]. These observations collectively suggest a possible mechanism of the impaired antiviral response in asthmatic patients. Although most experimental studies are performed in RV or influenza infection models, which are the most common respiratory viruses in asthma exacerbations, these findings still display a general pattern of antiviral responses. Another thing worth noting is that the expression of
IFNs is comparable to that in healthy controls when atopic diseases are mild or easily controlled [30], indicating the importance of controlling disease activity.

It should also be noted that CoVs can shield themselves from cytosol sensors and actively counteract host innate immune responses [8]. For example, the dephosphorylation and deubiquitination ability of SARS-CoV is able to inhibit IFN signalling $[31,32]$. It is difficult to estimate to what degree the innate immune response would be reduced during $\mathrm{CoV}$ infection in asthmatic individuals. However, considering that the pathogenesis of SARS is often associated with abnormal, overactivated innate immunity [32], the influence of an attenuated immune response on the disease course of SARS-CoV2 infection may be comprehensive and individualized.

\section{CoV Infection and Eosinophil Inflammation}

It is well known that eosinophils play a central role in allergic diseases, including asthma. The potential effects of eosinophils on $\mathrm{CoV}$ are also noteworthy. Previous experimental studies have indicated a potential role of eosinophils in promoting viral clearance and antiviral host defense, although this phenomenon is not observed in all circumstances [33]. In vitro studies have shown that recombinant eosinophil-derived neurotoxin (a major eosinophil ribonuclease) is capable of reducing the infectivity of respiratory syncytial virus (RSV), which can be reversed by a ribonuclease inhibitor [34], suggesting the possibility that eosinophils are able to target the singlestranded RNA (ssRNA) genome of respiratory viruses (such as RSV) with their secretory ribonucleases. In addition, eosinophils can be activated with ssRNA through triggering the TLR-7-MyD88 signalling pathway, which might result in RSV clearance and limitation of virus-induced lung dysfunction [35]. The capacity of eosinophils to protect against viral infection [36] might therefore account for a low prevalence of asthmatic individuals among patients with COVID-19.

Interestingly, some studies have shown eosinopenia in COVID-19 patients, which is more prominent in severe patients than in mild patients $[15,37]$. The eosinophil count returns to normal after sustained usage of lopinavir, suggesting that an increase in eosinophils may serve as an indicator of COVID-19 improvement [38]. In addition, eosinopenia has also been reported in SARS-CoV [39, 40] and MERS-CoV infections [41]. However, whether such eosinopenia is the result of generally impaired immunity (including Th2 cells and Th2 cytokine production) or whether it is the result of direct virus targeting still needs to be clarified. Nevertheless, it would be intriguing to explore the role of eosinophils in SARS-CoV-2 infection and the potential influence of allergy-elicited eosinophilic inflammation on the course of COVID-19. For example, we need to know whether preexisting eosinophilia in asthmatic patients counteracts the reduction of eosinophils during the disease course of COVID- 
19. Whether tissue infiltration of eosinophils promotes viral clearance and antiviral host defense in asthmatic patients needs to be explored. Further observations, of course, are needed to verify this theoretical protective role of eosinophils in SARS-CoV-2 infection and the potential influence of allergy-elicited eosinophilic inflammation on COVID-19 disease course.

\section{Viral-Induced Asthma Exacerbations}

Respiratory virus infection accounts for up to $80 \%$ of acute exacerbations of asthma in children and half of such episodes in adults, among which RV is the most common cause [42, 43]. Message et al. have shown that in response to RV infection, asthmatic individuals have increased clinical severity, impaired lung function, bronchial hyperreactivity, and eosinophilic inflammation, which affect the virologic and clinical outcomes, possibly related to augmented Th2 or impaired Th1 or IL-10 responses [44]. CoVs are also detected at a mean prevalence of $8.4 \%$ in asthma exacerbations [45]. Most interestingly, there are no reports regarding asthma exacerbation due to COVID-19. Correspondingly, there are few reports on asthma exacerbations during the SARS and MERS epidemics [46]. These phenomena, notably, still need to be well documented.

\section{Are Asthma Patients at an Increased Risk of COVID- 19 ?}

Considering that asthmatic patients have impaired immune responses against virus infection and that respiratory viral infections have the potential to trigger or worsen asthma symptoms, the management of asthma patients becomes more complex during the COVID-19 pandemic. Theoretically, it seems that pre-existing asthma has a potential influence on SARSCoV-2 susceptibility and disease course. However, existing studies have not indicated a high prevalence of asthma among COVID-19 patients. Throughout the published studies on COVID-19, few studies have listed asthma as a comorbidity, which is insufficient to support any solid conclusion. According to the China Centers for Disease Control (CDC), only $2.4 \%$ of 44,672 patients had chronic respiratory disease (including asthma) [47]. Another study reported no physiciandiagnosed asthma among 1590 patients in China [48]. Gao et al. reported on 140 COVID-19 patients in Wuhan, China, among whom $11.4 \%$ were hypersensitive to certain drugs, and $1.4 \%$ had urticaria, but no patients had asthma or other allergic diseases [37]. In another case series reported by the same team, patients with common allergic diseases (1 child with allergic rhinitis, 1 child with atopic dermatitis, and 1 adult with chronic urticaria) did not have symptoms distinct from those of other COVID-19 patients and did not develop severe courses [49]. To support this result, the authors also mentioned that they did not find asthma history among pediatric COVID-19 patients (number not known, data unpublished) [49]. A study from Lombardy, Italy has also shown relatively low prevalence of asthma [50]. Only statistics from New York City, USA, shows a 9\% prevalence of asthma [51], although there is no clear identification of the precise clinical phenotypes and treatments of the patients included. However, asthma is absent from the top 10 comorbidities according to the fatality statistics of the New York State [52]. These results collectively suggest that allergic diseases may not be a predisposing or aggravating factor for COVID-19. Table 2 summarizes the prevalence of asthma reported in patients with COVID-19.

Some type 2 cytokines, such as IL-4, IL-13, and IL-9, also have anti-inflammatory effects [53]. For example, IL-4 can not only suppress development of Th1 cells from the Th0 activated stage but also inhibit production of multiple proinflammatory cytokines, including IL- $1 \beta$, TNF- $\alpha$, IL-6, and IL-12 $[54,55]$. It has been also shown that IL-13 has immunoregulatory effects through inhibiting the secretion of proinflammatory cytokines (IL- $1 \alpha$, IL- $1 \beta$, IL- 6 , and TNF- $\alpha$ ) and chemokines (IL-8, MIP- $1 \alpha$ and MIP-1 $\beta$, and monocyte chemotactic protein-3) [56]. Furthermore, IL-9 reduces the secretion of TNF- $\alpha$ and IL-10, but increases the secretion of transforming growth factor beta $(\mathrm{TGF}-\beta)$ on LPS-activated
Table 2 Prevalence of asthma in patients with COVID-19

\begin{tabular}{lllll}
\hline Population & $\begin{array}{l}\text { Number of } \\
\text { patients }\end{array}$ & $\begin{array}{l}\text { Mean or median } \\
\text { age (years) }\end{array}$ & Prevalence $(\%)$ & Reference \\
\hline China & 44,672 & NA & $\begin{array}{l}2.4 \% \text { for chronic respiratory disease (not } \\
\text { specified for asthma) }\end{array}$ & {$[47]$} \\
China & 1590 & 48.9 & $0 \%$ & {$[48]$} \\
Wuhan, China & 140 & 57 & $0 \%$ & {$[37]$} \\
$\begin{array}{l}\text { Lombardy, } \\
\quad 1 t a l y\end{array}$ & 1591 & 63 & $<3 \%$ (not specified)* & {$[50]$} \\
$\begin{array}{l}\text { New York } \\
\text { City, USA }\end{array}$ & 5700 & 63 & $9 \%$ & {$[51]$} \\
\hline
\end{tabular}

COVID-19, coronavirus disease 2019. *Comorbidities with prevalence no less than $3 \%$ were listed as separate items, while asthma was counted as "others" with unspecified prevalence 
monocytes [57]. It is possible, therefore, that predominance of type 2 cytokines might counteract the accumulation of proinflammatory cytokines to some extent, including the pathogenesis of COVID-19.

On the other hand, the expression of ACE2, which is the entry receptor for SARS-CoV-2, might be affected by asthmatic conditions. Through examining the RNA-seq data in airway cells from 3 different cohorts, a recent study has reported that respiratory allergy and controlled allergen exposures are associated with significant reductions in ACE2 expression [58]. Another study has also shown that type I IFNs, and to a lesser extent type II IFNs, upregulate the expression ACE2, indicating that SARS-CoV-2 might exploit host antiviral defense to facilitate its entry into target cells [59]. Considering that higher ACE2 expression increases in vitro susceptibility to SARS$\mathrm{CoV}$, the general deficient IFN responses in asthmatic patients might reduce the virus invasion, at least partially through limiting the ACE2 expression on the target cells.

Currently, it is still not known whether a distinct type 2 immune response contributes to certain protection of allergic patients from COVID-19. Clearly, wide and large-scale investigations are expected to further elucidate the interactions between COVID-19 and asthma.

\section{Asthma Therapeutics and COVID-19}

Additional major concerns are whether therapeutics for asthma (including corticosteroids, allergen-specific immunotherapy (AIT), monoclonal antibodies, leukotriene antagonists, bronchodilators) affect the immune system, which in turn reduces COVID-19 infection, and whether these medications would influence the biological behavior of SARS-CoV-2 in the human body.

\section{Inhaled Corticosteroids}

High-dose corticosteroids have been used $\alpha$ during the SARS and MERS outbreaks and in COVID-19 to suppress lung inflammation during critical illness of infected patients. Despite association with delayed viral RNA clearance and increased risks of secondary infections [60], corticosteroid usage has been supported by some studies for benefits that likely outweigh the adverse effects $[14,61]$. Since the clinical evidence for the usage of corticosteroids in COVID-19 is still insufficient, the corticosteroids given to COVID-19 patients, only if necessary, should be cautiously administered, with strict restrictions on indications and dosage [62].

However, low-dose inhaled corticosteroids are routinely used by a considerable proportion of asthma patients on a daily basis. One important question is whether inhaled corticosteroids, often along with beta2-agonists and/or muscarinic antagonists, would affect the disease course and severity of
COVID-19. Previous studies have indicated that inhaled corticosteroids can reduce pro-inflammatory cytokine levels (including MIP- $1 \alpha$, GM-CSF, TNF- $\alpha$, and IL-1R $\alpha$ ) and increase anti-inflammatory cytokine levels (IL-10) in asthma patients $[63,64]$. It is, therefore, very possible that the lowdose, inhaled corticosteroids exert protective effects on asthma patients by reducing airway inflammation, if any, in the early stage of SARS-CoV infection. In addition, an in vitro experimental study has shown that glycopyrronium, formoterol, and a combination of glycopyrronium, formoterol, and budesonide are capable of reducing HCoV-229E replication, partly by inhibiting receptor expression and/or endosomal function [65]. Considering the difference in the features of the viruses, the results for HCoV-229E should be interpreted cautiously. However, the potential antiinflammatory and antiviral effects of low-dose, inhaled corticosteroids on asthmatic patients certainly deserve further investigation.

In addition, it has been known that glucocorticoid receptors are essential in determining glucocorticoid responsiveness, while alterations in number, splicing pattern, and epigenetic changes of the receptors may play a role in glucocorticoidresistant asthma [66]. It is reasonable to speculate that there might also be a difference in severity and disease course of COVID-19 between asthmatic patients who are sensitive or non-sensitive to steroids. Are there any changes in the glucocorticoid receptors which might account for less effectiveness in the treatment with steroids in COVID-19? Whether glucocorticoid receptors play a role in the effectiveness of steroid treatment in COVID-19 deserves to be further clarified.

\section{AIT}

AIT has been used in allergic diseases for more than 100 years, and many new therapeutic advances have been introduced in recent years. The underlying mechanisms of AIT include the very early desensitization effect, modulation of $\mathrm{T}$ and $\mathrm{B}$ cell responses, and prevention of tissue homing and degranulation of allergy effector cells (mast cells, basophils, and eosinophils) [67]. An essential process of AIT is the generation and maintenance of functional allergen-specific regulatory $\mathrm{T}$ (Treg) cells and regulatory B (Breg) cells [68]. Treg cells, together with their inhibitory cytokines, such as IL-10 and TGF- $\beta$, suppress Th2 immune responses and control allergic inflammation [68]. In addition, it is recognized that Treg cells play a role in preventing cytokine storms and limiting tissue damage [69, 70]. Considering the putative pathomechanism of cytokine storms in severe COVID-19 patients, it is possible that the immune tolerance induced by AIT might have a protective role. Of course, this concept is putative and it necessitates further examination. 


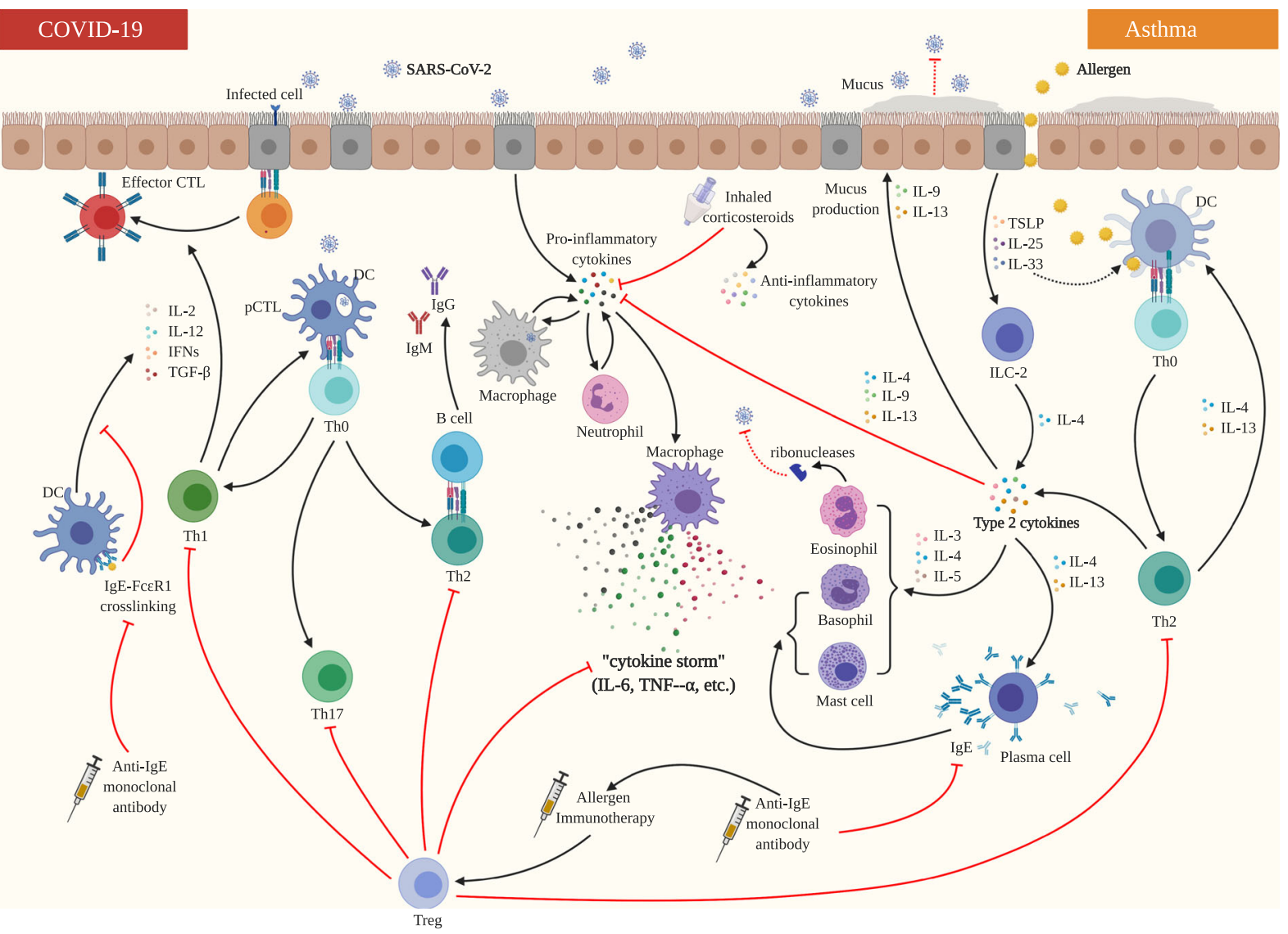

After SARS-CoV-2 enters the host cell, the activation of innate immune system leads to release of proinflammatory cytokines (IL-6, TNF- $\alpha$, etc.), which recruits effector cells (neutrophils, macrophages, etc.) and activates the cascade cytokine release. As for the adaptive immune response, antigen-presenting cells (APCs, referring to dendritic cells in this figure) present CoV antigen to T cells, eliciting the differentiation of Th0 cells into Th1, Th2, and Th17 subsets. Cytotoxic T cells, natural killer cells (NK), and natural killer T cells (NKT) might also participate in killing the virus-infected cells (the cells not shown in the diagram). These cell mediate cellular and humoral immunity, respectively. Orchestration between the innate and adaptive immune systems is essential in the antiviral responses. If adaptive immune responses are insufficient to eliminate the virus, innate immune responses are likely to be reinforced, which may lead to uncontrollable release of proinflammatory cytokines (i.e., the"cytokine storm"), which is supposed to be a potential pathological mechanism for rapid progression of this disease. In asthma, environmental allergens are uptaken by dendritic cells and then presented to Th0 cells. With the presence of IL-4, Th0 cells differentiate into Th2 subsets and produce Type 2 cytokines (IL-4, IL-5, IL-13, etc.). Epithelium-derived IL-33, IL-25, and TSLP also contribute to the accumulation of Type 2 cytokines through stimulating ILC2, and possibly acting on DC. All these lead to type 2 immune responses causing pathophysiological changes in asthma, including IgE production, local eosinophilia, mucus production, and activation of effector cells, such as eosinophils, basophils, and mast cells. Type 2 immune responses and conventional asthma therapeutics (red dashed or solid lines) might provide potential protective effects against infection with SARS-CoV-2. Some type 2 cytokines can inhibit the production of pro-inflammatory cytokines. Mucus lining the epithelium might serve as the physical barrier blocking invasion of the virus. Ribonucleases released by activated eosinophils might act on viral clearance. The routine usage of low-dose inhaled corticosteroids might attenuate early airway inflammation caused by virus infection, while regulatory $\mathrm{T}$ cells (Tregs) induced by allergen immunotherapy might also suppress inflammation and limit tissue damage by downregulating the induction and proliferation of other $\mathrm{T}$ cell subsets. Treatment with anti-IgE monoclonal antibody normally provides benefits in asthma through blockade of binding free form of IgE to FceRI (IgE high affinity receptor) on effector cells (such as mast cells and basophils). Anti-IgE monoclonal antibody has a synergistic effect on allergen immuno therapy through inducing development of Treg cells. Furthermore, treatment with anti-IgE antibodies might also enhance produc tion of IFNs through prevention of cross-linking of IgE-FceRI on dendritic cells. CTL, cytotoxic T lymphocyte; DC, dendritic cell; Ig, immunoglobulin; IL, interleukin; ILC-2, group 2 innate lymphoid cell; pCTL, precursor cytotoxic T lymphocyte; SARS-CoV-2, severe acute respiratory syndrome coronavirus-2; Th0, naïve T cell; Th1, T helper 1 cell; Th2, T helper 2 cell; Th17, T helper 17 cell; Treg, regulatory T cells; TSLP, thymic stromal lymphopoietin

Fig. 1 The schematic presentation of putative interactions between COVID-19 and asthma 


\section{Anti-IgE Monoclonal Antibody}

As stated earlier, cross-linking IgE-FceRI (its high affinity receptor) dampens antiviral responses in asthmatic patients, which has led to research on anti-IgE monoclonal antibodies. Since 2003, omalizumab, a monoclonal antibody against human IgE, has been approved for the treatment of severe, persistent asthma. As expected, recent studies have shown that blocking IgE could reduce susceptibility to respiratory virus infection through enhancing IFN- $\alpha$ signalling in pDCs [71-73]. In the Preventative Omalizumab or Step-up Therapy for Severe Fall Exacerbations (PROSE) study, omalizumab treatment was able to decrease RV infection duration, viral clearance, and RV illness frequency [72]. In a randomized, multicentre clinical trial, omalizumab improved IFN- $\alpha$ signalling in response to $\mathrm{RV}$ infection, which was associated with reduced asthma exacerbations [71]. Another study has also shown the effect of omalizumab on increasing $\mathrm{pDC}$ IFN- $\alpha$ responses but reducing the expression of $\mathrm{pDC}$ FceRI $\alpha$ in children with asthma [73]. In addition, IL-33 levels decrease after omalizumab treatment $[74,75]$, which induces the production of pro-inflammatory cytokines (including IL-6, IL-1 $\beta$, TNF- $\alpha$, MCP-1, and prostaglandin D2) [76]. Taken together, these observations suggest a potential effect of omalizumab on antiviral responses. It would be intriguing to explore whether previous or concurrent use of omalizumab has potential protective effects on COVID-19 infection, on either duration or severity or both. A putative diagram showing the potential mechanisms by which asthmatic individuals "escape" from COVID-19 is shown in Fig. 1.

Considering the potential protective effects of asthma therapeutics, and the increased risk of nosocomial infections with exacerbations, we recommend that asthmatic patients continue taking the prescribed medications during the pandemic.

\section{Conclusion}

Despite deficient antiviral immune responses and the tendency for acute exacerbation, there is little evidence showing that asthma patients have increased susceptibility or severity of SARS$\mathrm{CoV}-2$ infection than others. It is particularly intriguing to explore whether features of the disease, type 2 immune response, asthma therapeutics, or all of them are capable of providing certain protective effects against COVID-19. Notably, further clinical and basic studies are expected to explore the relationship between COVID-19 and asthma and/or other allergic diseases.

Acknowledgments The artwork was created with BioRender.com.

Author Contributions All authors participated in the conceptual design. SL drafted the manuscript. All authors participated in reviewing and editing the manuscript and in the approval of finalized manuscript.

\section{Compliance with Ethical Standards}

Conflict of Interest The authors declare that they have no conflicts of interest.

\section{References}

1. Zhou P, Yang XL, Wang XG, Hu B, Zhang L, Zhang W, Si HR, Zhu Y, Li B, Huang CL, Chen HD, Chen J, Luo Y, Guo H, Jiang RD, Liu MQ, Chen Y, Shen XR, Wang X, Zheng XS, Zhao K, Chen QJ, Deng F, Liu LL, Yan B, Zhan FX, Wang YY, Xiao GF, Shi ZL (2020) A pneumonia outbreak associated with a new coronavirus of probable bat origin. Nature 579(7798):270-273. https:// doi.org/10.1038/s41586-020-2012-7

2. Wang W, Xu Y, Gao R, Lu R, Han K, Wu G, Tan W (2020) Detection of SARS-CoV-2 in different types of clinical specimens. Jama. https://doi.org/10.1001/jama.2020.3786

3. Liang Peng JL, Xu W, Luo Q, Deng K, Lin B, Gao Z (2020) 2019 Novel coronavirus can be detected in urine, blood, anal swabs and oropharyngeal swabs samples. medRxiv 20026179. doi:https://doi. org $/ 10.1101 / 2020.02 .21 .20026179$

4. Huang C, Wang Y, Li X, Ren L, Zhao J, Hu Y, Zhang L, Fan G, Xu J, Gu X, Cheng Z, Yu T, Xia J, Wei Y, Wu W, Xie X, Yin W, Li H, Liu M, Xiao Y, Gao H, Guo L, Xie J, Wang G, Jiang R, Gao Z, Jin Q, Wang J, Cao B (2020) Clinical features of patients infected with 2019 novel coronavirus in Wuhan, China. Lancet 395(10223):497506. https://doi.org/10.1016/s0140-6736(20)30183-5

5. Chen N, Zhou M, Dong X, Qu J, Gong F, Han Y, Qiu Y, Wang J, Liu Y, Wei Y, Xia J, Yu T, Zhang X, Zhang L (2020) Epidemiological and clinical characteristics of 99 cases of 2019 novel coronavirus pneumonia in Wuhan, China: a descriptive study. Lancet 395(10223):507-513. https://doi.org/10.1016/ s0140-6736(20)30211-7

6. Lauer SA, Grantz KH, Bi Q, Jones FK, Zheng Q, Meredith HR, Azman AS, Reich NG, Lessler J (2020) The incubation period of coronavirus disease 2019 (COVID-19) from publicly reported confirmed cases: estimation and application. Ann Intern Med 172:577. https://doi.org/10.7326/m20-0504

7. Li LQ, Huang T, Wang YQ, Wang ZP, Liang Y, Huang TB, Zhang HY, Sun W, Wang Y (2020) COVID-19 patients' clinical characteristics, discharge rate, and fatality rate of meta-analysis. J Med Virol 92:577-583. https://doi.org/10.1002/jmv.25757

8. de Wilde AH, Snijder EJ, Kikkert M, van Hemert MJ (2018) Host factors in coronavirus replication. Curr Top Microbiol Immunol 419:1-42. https://doi.org/10.1007/82_2017_25

9. Yang J, Zheng Y, Gou X, Pu K, Chen Z, Guo Q, Ji R, Wang H, Wang Y, Zhou Y (2020) Prevalence of comorbidities in the novel Wuhan coronavirus (COVID-19) infection: a systematic review and meta-analysis. Int J Infect Dis 94:91-95. https://doi.org/10. 1016/j.ijid.2020.03.017

10. Huang K, Yang T, Xu J, Yang L, Zhao J, Zhang X, Bai C, Kang J, Ran P, Shen H, Wen F, Chen Y, Sun T, Shan G, Lin Y, Xu G, Wu S, Wang C, Wang R, Shi Z, Xu Y, Ye X, Song Y, Wang Q, Zhou Y, Li W, Ding L, Wan C, Yao W, Guo Y, Xiao F, Lu Y, Peng X, Zhang B, Xiao D, Wang Z, Chen Z, Bu X, Zhang H, Zhang X, An L, Zhang S, Zhu J, Cao Z, Zhan Q, Yang Y, Liang L, Tong X, Dai H, Cao B, Wu T, Chung KF, He J, Wang C (2019) Prevalence, risk factors, and management of asthma in China: a national crosssectional study. Lancet 394(10196):407-418. https://doi.org/10. 1016/s0140-6736(19)31147-x

11. Loftus PA, Wise SK (2016) Epidemiology of asthma. Curr Opin Otolaryngol 24(3):245-249. https://doi.org/10.1097/moo. 0000000000000262 
12. Li G, Fan Y, Lai Y, Han T, Li Z, Zhou P, Pan P, Wang W, Hu D, Liu X, Zhang Q, Wu J (2020) Coronavirus infections and immune responses. J Med Virol 92(4):424 432. https://doi.org/10.1002/jmv.25685

13. Braciale TJ, Sun J, Kim TS (2012) Regulating the adaptive immune response to respiratory virus infection. Nat Rev Immunol 12(4): 295-305. https://doi.org/10.1038/nri3166

14. Zhang W, Zhao Y, Zhang F, Wang Q, Li T, Liu Z, Wang J, Qin Y, Zhang X, Yan X, Zeng X, Zhang S (2020) The use of antiinflammatory drugs in the treatment of people with severe coronavirus disease 2019 (COVID-19): the perspectives of clinical immunologists from China. Clin Immunol 214:108393. https://doi.org/ 10.1016/j.clim.2020.108393

15. Qin C, Zhou L, Hu Z, Zhang S, Yang S, Tao Y, Xie C, Ma K, Shang K, Wang W, Tian DS (2020) Dysregulation of immune response in patients with COVID-19 in Wuhan, China. Clin Infect Dis. https://doi.org/10.1093/cid/ciaa248

16. Chen G, Wu D, Guo W, Cao Y, Huang D, Wang H, Wang T, Zhang X, Chen H, Yu H, Zhang X, Zhang M, Wu S, Song J, Chen T, Han M, Li S, Luo X, Zhao J, Ning Q (2020) Clinical and immunologic features in severe and moderate coronavirus disease 2019. J Clin Invest 130:2620-2629. https://doi.org/10.1172/jci137244

17. Bo Diao CW, Tan Y, Chen X, Liu Y, Ning L, Chen L, Li M, Liu Y, Wang G, Yuan Z, Feng Z, Wu Y, Chen Y (2020) Reduction and functional exhaustion of $t$ cells in patients with coronavirus disease 2019 (COVID-19). medRxiv:20024364. https://doi.org/10.1101/ 2020.02.18.20024364

18. Wenjun Wang JH Jr, Lie P, Huang L, Wu S, Lin Y, Liu X (2020) The definition and risks of cytokine release syndrome-like in 11 COVID-19-infected pneumonia critically ill patients: disease characteristics and retrospective analysis. medRxiv:20026989. https:// doi.org/10.1101/2020.02.26.20026989

19. Suxin Wan QY, Fan S, Lv J, Zhang X, Guo L, Lang C, Xiao Q, Xiao K, Yi Z, Qiang M, Xiang J, Zhang B, Chen Y (2020) Characteristics of lymphocyte subsets and cytokines in peripheral blood of 123 hospitalized patients with 2019 novel coronavirus pneumonia (NCP). medRxiv 2020(20021832). https://doi.org/10. $1101 / 2020.02 .10 .20021832$

20. Mehta P, McAuley DF, Brown M, Sanchez E, Tattersall RS, Manson JJ (2020) COVID-19: consider cytokine storm syndromes and immunosuppression. Lancet 395(10229):1033-1034. https:// doi.org/10.1016/s0140-6736(20)30628-0

21. Tian S, Hu W, Niu L, Liu H, Xu H, Xiao SY (2020) Pulmonary pathology of early-phase 2019 novel coronavirus (COVID-19) pneumonia in two patients with lung cancer. J Thorac Oncol 15: 700-704. https://doi.org/10.1016/j.jtho.2020.02.010

22. Xu Z, Shi L, Wang Y, Zhang J, Huang L, Zhang C, Liu S, Zhao P, Liu H, Zhu L, Tai Y, Bai C, Gao T, Song J, Xia P, Dong J, Zhao J, Wang FS (2020) Pathological findings of COVID-19 associated with acute respiratory distress syndrome. Lancet Respir Med 8: 420-422. https://doi.org/10.1016/s2213-2600(20)30076-x

23. Chaofu Wang JX, Zhao L et al (2020) Aveolar macrophage activation and cytokine storm in the pathogenesis of severe COVID-19. PREPRINT (Version 1) available at Research Square. doi:https:// doi.org/10.21203/rs.3.rs-19346/v1+

24. Agache I, Akdis CA (2016) Endotypes of allergic diseases and asthma: An important step in building blocks for the future of precision medicine. Allergol Int 65(3):243-252. https://doi.org/10. 1016/j.alit.2016.04.011

25. Breiteneder H, Diamant Z, Eiwegger T, Fokkens WJ, TraidlHoffmann C, Nadeau K, O'Hehir RE, O'Mahony L, Pfaar O, Torres MJ, Wang Y, Zhang L, Akdis CA (2019) Future research trends in understanding the mechanisms underlying allergic diseases for improved patient care. Allergy 74(12):2293-2311. https://doi.org/10.1111/all.13851
26. Gonzales-van Horn SR, Farrar JD (2015) Interferon at the crossroads of allergy and viral infections. J Leukoc Biol 98(2):185-194. https://doi.org/10.1189/jlb.3RU0315-099R

27. Cakebread JA, Xu Y, Grainge C, Kehagia V, Howarth PH, Holgate ST, Davies DE (2011) Exogenous IFN-beta has antiviral and antiinflammatory properties in primary bronchial epithelial cells from asthmatic subjects exposed to rhinovirus. J Allergy Clin Immunol 127(5):1148-1154.e1149. https://doi.org/10.1016/j.jaci.2011.01.023

28. Zhu J, Message SD, Mallia P, Kebadze T, Contoli M, Ward CK, Barnathan ES, Mascelli MA, Kon OM, Papi A, Stanciu LA, Edwards MR, Jeffery PK, Johnston SL (2019) Bronchial mucosal IFN-alpha/beta and pattern recognition receptor expression in patients with experimental rhinovirus-induced asthma exacerbations. J Allergy Clin Immunol 143(1):114-125.e114. https://oi.org/10. 1016/j.jaci.2018.04.003

29. Contoli M, Message SD, Laza-Stanca V, Edwards MR, Wark PA, Bartlett NW, Kebadze T, Mallia P, Stanciu LA, Parker HL, Slater L, Lewis-Antes A, Kon OM, Holgate ST, Davies DE, Kotenko SV, Papi A, Johnston SL (2006) Role of deficient type III interferonlambda production in asthma exacerbations. Nat Med 12(9):10231026. https://doi.org/10.1038/nm1462

30. Gill MA, Bajwa G, George TA, Dong CC, Dougherty II, Jiang N, Gan VN, Gruchalla RS (2010) Counterregulation between the FcepsilonRI pathway and antiviral responses in human plasmacytoid dendritic cells. J Immunol 184(11):5999-6006. https://doi.org/10.4049/jimmunol.0901194

31. Wathelet MG, Orr M, Frieman MB, Baric RS (2007) Severe acute respiratory syndrome coronavirus evades antiviral signaling: role of nsp1 and rational design of an attenuated strain. J Virol 81(21): 11620-11633. https://doi.org/10.1128/jvi.00702-07

32. Gu J, Korteweg C (2007) Pathology and pathogenesis of severe acute respiratory syndrome. Am J Pathol 170(4):1136-1147. https://doi.org/10.2353/ajpath.2007.061088

33. Rosenberg HF, Dyer KD, Domachowske JB (2009) Respiratory viruses and eosinophils: exploring the connections. Antivir Res 83(1):1-9. https://doi.org/10.1016/j.antiviral.2009.04.005

34. Domachowske JB, Dyer KD, Bonville CA, Rosenberg HF (1998) Recombinant human eosinophil-derived neurotoxin/RNase 2 functions as an effective antiviral agent against respiratory syncytial virus. J Infect Dis 177(6):1458-1464. https://doi.org/10.1086/ 515322

35. Phipps S, Lam CE, Mahalingam S, Newhouse M, Ramirez R, Rosenberg HF, Foster PS, Matthaei KI (2007) Eosinophils contribute to innate antiviral immunity and promote clearance of respiratory syncytial virus. Blood 110(5):1578-1586. https://doi.org/10. 1182/blood-2007-01-071340

36. Rosenberg HF, Dyer KD, Domachowske JB (2009) Eosinophils and their interactions with respiratory virus pathogens. Immunol Res 43(1-3):128-137. https://doi.org/10.1007/s12026-008-8058-5

37. Zhang JJ, Dong X, Cao YY, Yuan YD, Yang YB, Yan YQ, Akdis CA, Gao YD (2020) Clinical characteristics of 140 patients infected with SARS-CoV-2 in Wuhan, China. Allergy. https://doi.org/10. 1111/all.14238

38. Liu F, Xu A, Zhang Y, Xuan W, Yan T, Pan K, Yu W, Zhang J (2020) Patients of COVID-19 may benefit from sustained lopinavir-combined regimen and the increase of eosinophil may predict the outcome of COVID-19 progression. International journal of infectious diseases : IJID : official publication of the International Society for Infectious Diseases 95:183-191. https:// doi.org/10.1016/j.ijid.2020.03.013

39. Yao X-a, Zhao Y-e, Tong Y-w, Tang X-p, Yin C-b (2003) Determination and analysis of blood eosinophil in 200 severe acute respiratory syndrome patients (in Chinese). Lab Med 019(5):444-445

40. Rao W-m, Zeng Z-w, Feng T-b, He L-y (2003) Changes in blood eosinophil count in SARS patients (in Chinese). Chin Med J 83(19): $1715-1716$ 
41. Hwang SM, Na BJ, Jung Y, Lim HS, Seo JE, Park SA, Cho YS, Song EH, Seo JY, Kim SR, Lee GY, Kim SJ, Park YS, Seo H (2019) Clinical and laboratory findings of Middle East respiratory syndrome coronavirus infection. Jpn J Infect Dis 72(3):160-167. https://doi.org/10.7883/yoken.JJID.2018.187

42. Johnston SL, Pattemore PK, Sanderson G, Smith S, Lampe F, Josephs L, Symington P, O'Toole S, Myint SH, Tyrrell DA et al (1995) Community study of role of viral infections in exacerbations of asthma in 9-11 year old children. BMJ (Clinical research ed) 310(6989):1225-1229. https://doi.org/10.1136/bmj.310.6989.1225

43. Nicholson KG, Kent J, Ireland DC (1993) Respiratory viruses and exacerbations of asthma in adults. Br Med J 307(6910):982-986

44. Message SD, Laza-Stanca V, Mallia P, Parker HL, Zhu J, Kebadze T, Contoli M, Sanderson G, Kon OM, Papi A, Jeffery PK, Stanciu LA, Johnston SL (2008) Rhinovirus-induced lower respiratory illness is increased in asthma and related to virus load and Th1/2 cytokine and IL-10 production. Proc Natl Acad Sci U S A 105(36):13562-13567. https://doi.org/10.1073/pnas.0804181105

45. Zheng X-y, Xu Y-j, W-j G, Lin L-f (2018) Regional, age and respiratory-secretion-specific prevalence of respiratory viruses associated with asthma exacerbation: a literature review. Arch Virol 163(4):845-853. https://doi.org/10.1007/s00705-017-3700-y

46. Van Bever HP, Chng SY, Goh DY (2004) Childhood severe acute respiratory syndrome, coronavirus infections and asthma. Pediatr Allergy Immunol 15(3):206-209. https://doi.org/10.1111/j.13993038.2004.00137.x

47. The Novel Coronavirus Pneumonia Emergency Response Epidemiology Team (2020) The epidemiological characteristics of an outbreak of 2019 novel coronavirus diseases (COVID-19) - China, 2020. China CDC weekly. February 172020

48. Guan W-J, Liang W-H, Zhao Y, Liang H-R, Chen Z-S, Li Y-M, Liu X-Q, Chen R-C, Tang C-L, Wang T, Ou C-Q, Li L, Chen P-Y, Sang L, Wang W, Li J-F, Li C-C, Ou L-M, Cheng B, Xiong S, Ni Z-Y, Xiang J, Hu Y, Liu L, Shan H, Lei C-L, Peng Y-X, Wei L, Liu Y, Hu Y-H, Peng P, Wang J-M, Liu J-Y, Chen Z, Li G, Zheng Z-J, Qiu S-Q, Luo J, Ye C-J, Zhu S-Y, Cheng L-L, Ye F, Li S-Y, Zheng J-P, Zhang N-F, Zhong N-S, He J-X (2020) Comorbidity and its impact on 1590 patients with Covid-19 in China: a nationwide analysis. Eur Respir J:2000547. https://doi.org/10.1183/13993003. 00547-2020

49. Dong X, Cao YY, Lu XX, Zhang JJ, Du H, Yan YQ, Akdis CA, Gao YD (2020) Eleven faces of coronavirus disease 2019. Allergy. https://doi.org/10.1111/all.14289

50. Grasselli G, Zangrillo A, Zanella A, Antonelli M, Cabrini L, Castelli A, Cereda D, Coluccello A, Foti G, Fumagalli R, Iotti G, Latronico N, Lorini L, Merler S, Natalini G, Piatti A, Ranieri MV, Scandroglio AM, Storti E, Cecconi M, Pesenti A, Network ftC-LI (2020) Baseline characteristics and outcomes of 1591 patients infected with SARS-CoV-2 admitted to ICUs of the Lombardy region. JAMA 323:1574. https://doi.org/10.1001/jama.2020.5394

51. Richardson S, Hirsch JS, Narasimhan M, Crawford JM, McGinn T, Davidson KW, Barnaby DP, Becker LB, Chelico JD, Cohen SL, Cookingham J, Coppa K, Diefenbach MA, Dominello AJ, DuerHefele J, Falzon L, Gitlin J, Hajizadeh N, Harvin TG, Hirschwerk DA, Kim EJ, Kozel ZM, Marrast LM, Mogavero JN, Osorio GA, Qiu M, Zanos TP (2020) Presenting characteristics, comorbidities, and outcomes among 5700 patients hospitalized with COVID-19 in the New York City area. JAMA. https://doi.org/10.1001/jama. 2020.6775

52. New York State Department of Health COVID-19 Tracker-Fatality. https:/covid19tracker.health.ny.gov/views/NYS-COVID19Tracker/NYSDOHCOVID-19Tracker-Fatalities?\%3Aembed= yes\&\%3Atoolbar=no. Accessed Apr 302020

53. Dembic Z (2015) Chapter 6 - cytokines of the immune system: interleukins. In: Dembic Z (ed) The cytokines of the immune system. Academic Press, Amsterdam, pp 143-239. https://doi.org/ 10.1016/B978-0-12-419998-9.00006-7

54. te Velde AA, Huijbens RJ, Heije K, de Vries JE, Figdor CG (1990) Interleukin-4 (IL-4) inhibits secretion of IL-1 beta, tumor necrosis factor alpha, and IL-6 by human monocytes. Blood 76(7):1392-1397

55. Levings MK, Schrader JW (1999) IL-4 inhibits the production of TNF-alpha and IL-12 by STAT6-dependent and -independent mechanisms. J Immunol 162(9):5224-5229

56. de Vries JE (1998) The role of IL-13 and its receptor in allergy and inflammatory responses. J Allergy Clin Immunol 102(2):165-169. https://doi.org/10.1016/s0091-6749(98)70080-6

57. Pilette C, Ouadrhiri Y, Van Snick J, Renauld JC, Staquet P, Vaerman JP, Sibille Y (2002) IL-9 inhibits oxidative burst and TNF-alpha release in lipopolysaccharide-stimulated human monocytes through TGF-beta. J Immunol 168(8):4103-4111. https://doi. org/10.4049/jimmunol.168.8.4103

58. Jackson DJ, Busse WW, Bacharier LB, Kattan M, O'Connor GT, Wood RA, Visness CM, Durham SR, Larson D, Esnault S, Ober C, Gergen PJ, Becker P, Togias A, Gern JE, Altman MC (2020) Association of respiratory allergy, asthma and expression of the SARS-CoV-2 receptor, ACE2. J Allergy Clin Immunol. https:// doi.org/10.1016/j.jaci.2020.04.009

59. Ziegler CGK, Allon SJ, Nyquist SK, Mbano IM, Miao VN, Tzouanas CN, Cao Y, Yousif AS, Bals J, Hauser BM, Feldman J, Muus C, Wadsworth MH, Kazer SW, Hughes TK, Doran B, Gatter GJ, Vukovic M, Taliaferro F, Mead BE, Guo Z, Wang JP, Gras D, Plaisant M, Ansari M, Angelidis I, Adler H, Sucre JMS, Taylor CJ, Lin B, Waghray A, Mitsialis V, Dwyer DF, Buchheit KM, Boyce JA, Barrett NA, Laidlaw TM, Carroll SL, Colonna L, Tkachev V, Peterson CW, Yu A, Zheng HB, Gideon HP, Winchell CG, Lin PL, Bingle CD, Snapper SB, Kropski JA, Theis FJ, Schiller HB, Zaragosi L-E, Barbry P, Leslie A, Kiem H-P, Flynn JL, Fortune SM, Berger B, Finberg RW, Kean LS, Garber M, Schmidt AG, Lingwood D, Shalek AK, Ordovas-Montanes J (2020) SARSCoV-2 receptor ACE2 is an interferon-stimulated gene in human airway epithelial cells and is detected in specific cell subsets across tissues. Cell. https://doi.org/10.1016/j.cell.2020.04.035

60. Russell CD, Millar JE, Baillie JK (2020) Clinical evidence does not support corticosteroid treatment for 2019-nCoV lung injury. Lancet 395(10223):473-475. https://doi.org/10.1016/s0140-6736(20)30317-2

61. Wang D, Hu B, Hu C, Zhu F, Liu X, Zhang J, Wang B, Xiang H, Cheng Z, Xiong Y, Zhao Y, Li Y, Wang X, Peng Z (2020) Clinical characteristics of 138 hospitalized patients with 2019 novel coronavirus-infected pneumonia in Wuhan. China Jama 323: 1061. https://doi.org/10.1001/jama.2020.1585

62. Zhao JP, Hu Y, Du RH, Chen ZS, Jin Y, Zhou M, Zhang J, Qu JM, Cao B (2020) Expert consensus on the use of corticosteroid in patients with 2019-nCoV pneumonia (in Chinese). Zhonghua Jie He He Hu Xi Za Zhi 43(0):E007. https://doi.org/10.3760/cma.j. issn.1001-0939.2020.0007

63. John M, Lim S, Seybold J, Jose P, Robichaud A, O'Connor B, Barnes PJ, Chung KF (1998) Inhaled corticosteroids increase interleukin-10 but reduce macrophage inflammatory protein-1alpha, granulocyte-macrophage colony-stimulating factor, and interferon-gamma release from alveolar macrophages in asthma. Am J Respir Crit Care Med 157(1):256-262. https://doi.org/10. 1164/ajrccm.157.1.9703079

64. Baraket M, Oliver BG, Burgess JK, Lim S, King GG, Black JL (2012) Is low dose inhaled corticosteroid therapy as effective for inflammation and remodeling in asthma? A randomized, parallel group study. Respir Res 13:11. https://doi.org/10.1186/1465-9921-13-11

65. Yamaya M, Nishimura H, Deng X, Sugawara M, Watanabe O, Nomura K, Shimotai Y, Momma H, Ichinose M, Kawase T (2020) Inhibitory effects of glycopyrronium, formoterol, and budesonide on coronavirus HCoV-229E replication and cytokine production by primary cultures of human nasal and tracheal 
epithelial cells. Respir Investig 58:155-168. https://doi.org/10. 1016/j.resinv.2019.12.005

66. Trevor JL, Deshane JS (2014) Refractory asthma: mechanisms, targets, and therapy. Allergy 69(7):817-827. https://doi.org/10. 1111/all.12412

67. Akdis CA, Akdis M (2015) Mechanisms of allergen-specific immunotherapy and immune tolerance to allergens. World Allergy Organ 8(1):17. https://doi.org/10.1186/s40413-015-0063-2

68. Palomares O, Martin-Fontecha M, Lauener R, Traidl-Hoffmann C, Cavkaytar O, Akdis M, Akdis CA (2014) Regulatory T cells and immune regulation of allergic diseases: roles of IL-10 and TGF-beta. Genes Immun 15(8):511-520. https://doi.org/10.1038/gene.2014.45

69. Tatura R, Zeschnigk M, Hansen W, Steinmann J, Vidigal PG, Hutzler M, Pastille E, Westendorf AM, Buer J, Kehrmann J (2015) Relevance of Foxp3(+) regulatory T cells for early and late phases of murine sepsis. Immunology 146(1):144-156. https://doi. org/10.1111/imm.12490

70. Qiu D, Chu X, Hua L, Yang Y, Li K, Han Y, Yin J, Zhu M, Mu S, Sun Z, Tong C, Song Z (2019) Gpr174-deficient regulatory T cells decrease cytokine storm in septic mice. Cell Death Dis 10(3):233. https://doi.org/10.1038/s41419-019-1462-z

71. Teach SJ, Gill MA, Togias A, Sorkness CA, Arbes SJ Jr, Calatroni A, Wildfire JJ, Gergen PJ, Cohen RT, Pongracic JA, Kercsmar CM, Khurana Hershey GK, Gruchalla RS, Liu AH, Zoratti EM, Kattan M, Grindle KA, Gern JE, Busse WW, Szefler SJ (2015) Preseasonal treatment with either omalizumab or an inhaled corticosteroid boost to prevent fall asthma exacerbations. J Allergy Clin Immunol 136(6): 1476-1485. https://doi.org/10.1016/j.jaci.2015.09.008
72. Esquivel A, Busse WW, Calatroni A, Togias AG, Grindle KG, Bochkov YA, Gruchalla RS, Kattan M, Kercsmar CM, Khurana Hershey G, Kim H, Lebeau P, Liu AH, Szefler SJ, Teach SJ, West JB, Wildfire J, Pongracic JA, Gern JE (2017) Effects of omalizumab on rhinovirus infections, illnesses, and exacerbations of asthma. Am J Respir Crit Care Med 196(8):985-992. https://doi. org/10.1164/rccm.201701-0120OC

73. Gill MA, Liu AH, Calatroni A, Krouse RZ, Shao B, Schiltz A, Gern JE, Togias A, Busse WW (2018) Enhanced plasmacytoid dendritic cell antiviral responses after omalizumab. J Allergy Clin Immunol 141(5):1735-1743.e1739. https://doi.org/10.1016/j.jaci.2017.07.035

74. Yalcin AD, Uzun R (2019) Anti-IgE significantly changes circulating interleukin-25, vitamin-D and interleukin-33 levels in patients with allergic asthma. Curr Pharm Des 25(35):3784-3795. https:// doi.org/10.2174/1381612825666190930095725

75. Huang YC, Weng CM, Lee MJ, Lin SM, Wang CH, Kuo HP (2019) Endotypes of severe allergic asthma patients who clinically benefit from anti-IgE therapy. Clin Exp Allergy 49(1):44-53. https://doi.org/10.1111/cea.13248

76. Moulin D, Donze O, Talabot-Ayer D, Mezin F, Palmer G, Gabay C (2007) Interleukin (IL)-33 induces the release of pro-inflammatory mediators by mast cells. Cytokine 40(3):216-225. https://doi.org/ 10.1016/j.cyto.2007.09.013

Publisher's Note Springer Nature remains neutral with regard to jurisdictional claims in published maps and institutional affiliations. 